\title{
Celery (Apium graveolens L.), a new host of Pseudopyrenochaeta terrestris (former Pyrenochaeta lycopersici)
}

\author{
Loredana Sigillo $^{1}$ (D) Maria Aragona ${ }^{2} \cdot$ Maria Teresa Valente $^{2} \cdot$ Massimo Zaccardelli $^{1} \cdot$ Alessandro Infantino $^{2}$
}

Received: 23 October 2019 / Accepted: 6 February 2020 / Published online: 14 February 2020

(C) Società Italiana di Patologia Vegetale (S.I.Pa.V.) 2020

Keywords Celery $\cdot$ Pseudopyrenochaeta terrestris $\cdot$ Corky root rot $\cdot$ Soil borne pathogen $\cdot$ Pyrenochaeta lycopersici

In January 2019, celery (Apium graveolens L.) plants of cv. Utah, cultivated in an open field in Puglia (Italy), showed reduction of vigor and size, leaf yellowing and wilting with an incidence of about $50 \%$. Necroses were present on the roots and near the collar and the vascular tissues were dark; in some plants, soft rot occurred. To identify the causal agent of the disease, symptomatic basal tissues were disinfected in $1 \% \mathrm{NaOCl}$, rinsed with sterile water and plated onto potato dextrose agar (PDA), supplemented with streptomycin and chloramphenicol (50 ppm, each). To exclude the presence of bacterial infections, isolation on nutrient agar were also attempted. After two weeks of incubation at $22{ }^{\circ} \mathrm{C}$, colonies with a slow growing compact mycelium, initially creamy white and then dark grey, with brown reverse color, were observed. No pycnidia and conidia were present. These features resembled those of Pyrenochaeta spp. After PCR amplification of ITS region, using the primer pair ITS4 and ITS5 (White et al. 1990), one isolate, named ER 2186, produced a $600 \mathrm{bp}$ band that was sequenced and deposited in GenBank (accession number MN088821). Following Blast analyses, MN088821 showed a $100 \%$ homology with accessions NR_160575.1, AY649594.1 and AY649593.1, corresponding to the formerly named Pyrenochaeta lycopersici Type 1 (Infantino and Pucci 2005), now renamed Pseudopyrenochaeta terrestris sp. nov. (Valenzuela-Lopez et al. 2018). To verify the pathogenicity, five plugs of ER 2186 were added to $200 \mathrm{~g}$ of autoclaved pearl millet grains and incubated at $23^{\circ} \mathrm{C}$. After three

Loredana Sigillo

loredana.sigillo@crea.gov.it

1 Consiglio per la ricerca in agricoltura e l'analisi dell'economia agraria (CREA), Centro di ricerca orticoltura e florovivaismo, via Cavalleggeri, 25, Pontecagnano Faiano, 84098 Salerno, Italy

2 Consiglio per la ricerca in agricoltura e l'analisi dell'economia agraria (CREA), Centro di ricerca Difesa e Certificazione, Via C.G. Bertero, 22, 00156 Rome, Italy weeks, the inoculated millet was added to a mixture of peat and sand $(1: 7: 2 \mathrm{v} / \mathrm{v} / \mathrm{v})$ to obtain the final substrate in which five plants of celery cv. Utah, at five leaf stage, and five plants of tomato cv. Marmande, at third leaf stage, were transplanted. The plants were put in a phytotron at $23{ }^{\circ} \mathrm{C}$ with $12 \mathrm{~h} \mathrm{light/dark}$ photoperiod. Five plants of each species were used as controls. Two months after the inoculation, symptoms of necrosis were observed on the collar and roots, resembling those observed in the field. To fulfill the Kock's postulates, $P$. terrestris strain was re-isolated from both celery and tomato inoculated plants. To the best of our knowledge, this is the first report of P. terrestris affecting celery worldwide. This information is useful to provide efficient control strategies against the disease on celery and to establish correct crop rotations of other species susceptible to the fungus, even considering the major damages due to the synergistic association of nematodes with the closely related P. lycopersici (D'Errico et al. 2019).

\section{References}

D'Errico G, Marra R, Crescenzi A, Davino SW, Fanigliulo A, Woo SL, Lorito M (2019) Integrated management strategies of Meloidogyne incognita and Pseudopyrenochaeta lycopersici on tomato using a Bacillus firmus-based product and two synthetic nematicides in two consecutive crop cycles in greenhouse. Crop Prot 122:159-164

Infantino A, Pucci N (2005) A PCR-based assay for the identification and detection of Pyrenochaeta lycopersici. Eur J Plant Pathol 112:337-347

Valenzuela-Lopez N, Cano-Lira JF, Guarro J, Sutton DA, Wiederhold N, Crous PW, Stchigel AM (2018) Coelomycetous Dothideomycetes with emphasis on the families Cucurbitariaceae and Didymellaceae. Stud Mycol 90:1-69

White TJ, Bruns T, Lee S, Taylor J (1990) Amplification and direct sequencing of fungal ribosomal RNA genes for phylogenetics. In: Innis MA, Gelfand DH, Sninsky JJ, White TJ (eds) PCR protocols, a guide to methods and applications academic press. San Diego, USA, pp 315-322

Publisher's note Springer Nature remains neutral with regard to jurisdictional claims in published maps and institutional affiliations. 